\title{
Profile of packed lunches that meet the government school meal standards for England
}

\author{
C. E. L. Evans, D. C. Greenwood and J. E. Cade \\ University of Leeds, Leeds LS2 9JT, UK
}

Approximately half school pupils take a packed lunch from home ${ }^{(1)}$. With concerns over the nutritional content of school meals currently high on the political agenda, packed lunches are viewed by many parents as a healthier alternative. However, previous studies have shown that packed lunches are deficient in foods encouraged by the eatwell plate ${ }^{(2)}$. The present paper summarises the results of multilevel regression modelling on the association of types of food in children's packed lunches with the recently-introduced government school meal nutrient-based standards for England ${ }^{(3)}$.

In June 2006 baseline data (as part of a randomised controlled trial) were collected on the packed lunches of 1294 children aged 8-9 years in eighty-nine schools across England. The results revealed that packed lunches are poor in terms of food choice and nutrients, dominated by snack foods high in Na and non-milk extrinsic sugars (NMES) and low in foods high in starch and fibre ${ }^{(4,5)}$. The fourteen nutrient standards were originally compiled by the School Meal Review Panel ${ }^{(3)}$ and based on the Caroline Walker Trust guidelines ${ }^{(6)}$. They include maximum standards for total fat, saturated fat, NMES and Na; minimum standards for protein, carbohydrate, NSP, vitamin $\mathrm{A}$, vitamin $\mathrm{C}$, folate, $\mathrm{Ca}, \mathrm{Fe}$ and $\mathrm{Zn}$, as well as a maximum and minimum standard for energy.

One of the 1294 children's packed lunches met all fourteen of the nutrient standards. The mean number of standards met was six of fourteen nutrients. Regression modelling on individual nutrient standards revealed that certain food types were more likely to be found in lunches meeting more nutrient standards (see Table). More-nutritious lunches consisted of higher weights of vegetables, fruit, sandwiches, milk-based desserts and permitted drinks and lower weights of savoury snacks and confectionery.

\begin{tabular}{lccc}
\hline Food type & \multicolumn{2}{c}{$\begin{array}{c}\text { Mean wt (g) for lunches } \\
\text { meeting }>\text { eight standards }\end{array}$} & $\begin{array}{c}\text { Mean wt (g) for lunches } \\
\text { meeting }<\text { five standards }\end{array}$ \\
\hline Vegetables and $\quad 17$ & 3 & Weight ratio \\
$\quad$ salad & 138 & 28 & $5.7^{*}$ \\
Fruit & 160 & 63 & $4.9^{*}$ \\
Sandwich & 49 & 24 & $2.5^{*}$ \\
Milk-based dessert & 60 & 107 & $2.0^{*}$ \\
Permitted drinks & 186 & 166 & 6 \\
Sweetened drinks & 6 & 20 & $1.5^{*}$ \\
Cheese & 12 & 32 & 1.0 \\
Savoury snacks & 16 & $0.7 \dagger$ \\
Confectionery & 16 & $0.6 \dagger$ \\
\hline
\end{tabular}

* Statistically higher weights in lunches meeting more standards $(P<0.05)$

$\dagger$ Statistically lower weights in lunches meeting more standards $(P<0.05)$

A multilevel regression model containing all food types revealed that the foods most strongly associated with meeting more standards (excluding the standard for energy) were vegetables, fruit and sandwiches. Higher weights of confectionery and sweetened drinks (but not savoury snacks) were associated with exceeding the standard for energy.

Children should be encouraged to eat more sandwiches, vegetables and fruit and lower weights of sweetened drinks and confectionery to improve the nutritional quality of their packed lunch.

1. Gregory J \& Lowe S (2000) National Diet and Nutrition Survey: Young People Aged 4 to 18 Years. London: The Stationery Office.

2. Department of Health (2007) The eatwell plate. www.eatwell.gov.uk

3. School Food Trust (2007) Guide to the nutrient-based standards http://www.schoolfoodtrust.org.uk/content.asp?ContentId=641

4. Jefferson A \& Cowbrough K (2004) The School Lunchbox Survey http://www.food.gov.uk/multimedia/pdfs/lunchbox2004report.pdf

5. Evans CEL \& Cade JE (2007) Packed lunches in primary schools in the UK: A cluster randomised controlled trial of a 'Smart' lunch box, designed to improve the content of primary school children's packed lunches in the UK, part 1; results of baseline survey. http://www.food.gov.uk/multimedia/pdfs/ smartlunchbox.pdf

6. Caroline Walker Trust (2005) Nutrient-based standards for school food. http://www.cwt.org.uk/pdfs/eatingwell.pdf 